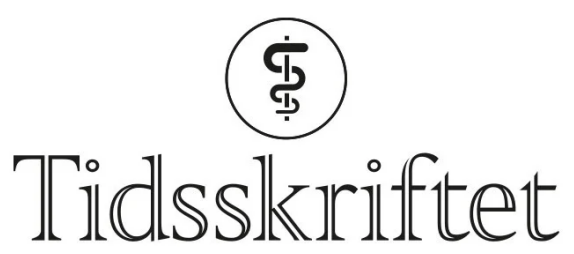

DEN NORSKE LEGEFORENING

\title{
Bedre oversikt over pankreaskreft i Norge
}

DEBATT

\section{HANNE HAMRE}

hannehamre@yahoo.no

Hanne Hamre er ph.d. og spesialist i onkologi ved Medisinsk avdeling, Akershus universitetssykehus. Forfatteren har fylt ut ICMJE-skjemaet og oppgir ingen interessekonflikter.

\section{KRISTOFFER LASSEN}

Kristoffer Lassen er dr.med. og seksjonsoverlege ved Seksjon for lever- og pankreaskirurgi (HPB), Gastrokirurgisk avdeling, Oslo universitetssykehus, Rikshospitalet og professor II ved Institutt for klinisk medisin, Universitetet i Troms $\emptyset$.

Forfatteren har fylt ut ICMJE-skjemaet og oppgir ingen interessekonflikter.

\section{Pankreaskreft har høy dødelighet og symptombyrde og rammer stadig flere nordmenn. Et dedikert kvalitetsregister kan bli avgjørende for å sikre god behandling.}

Femårsoverlevelsen av pankreaskreft (duktalt adenokarsinom) er under 10 \% (1). Insidensen av denne sykdommen er økende, den kirurgiske behandlingen omfattende, residivraten høy og symptombyrden betydelig. Uten store behandlingsgjennombrudd i sikte forventes

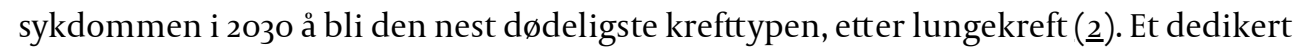
kvalitetsregister kan bli et avgjørende verktøy for å sikre at norske pankreaskreftpasienter får lik behandling med god kvalitet.

\section{Måling av kvalitet i alle faser}

Formålet med kvalitetsregisteret er å bedre pasientbehandlingen i alle stadier av sykdommen. Som for alle slike registre er det grunnleggende prinsippet å gjøre det viktige målbart, ikke å gjøre det målbare viktig. Vi skal registrere klinisk viktige variabler og tilstrebe komplett dekningsgrad med høy datakvalitet.

Det første steget er å gi en inngående beskrivelse av situasjonen i dag. Mindre enn 20 \% blir operert (3), og det er bare for de opererte prognosen er blitt klart forbedret, selv om de aller fleste får tilbakefall (4). Vi vet langt mindre om de som ikke blir operert. Hvordan 
funksjonsnivået er for de opererte etter utskrivning, har vi også svært lite kunnskap om. Bruk av kjemoterapi før og etter operasjon (neoadjuvant/adjuvant) og resultater av dette må beskrives bedre.

«Et dedikert kvalitetsregister kan bli et avgjørende verktøy for å sikre at norske pankreaskreftpasienter får lik behandling med god kvalitet»

I tillegg vet vi at så mange som $40 \%$ av nydiagnostiserte pankreaskreftpasienter ikke får noen tumorrettet behandling i det hele tatt (5). For denne undergruppen har det ikke vært målbar bedring i overlevelsen på over 20 år, og dette er pasientgruppen vi vet absolutt minst om. Vi må kartlegge hva slags vurdering som ligger bak en beslutning om ikke å starte tumorrettet behandling. Sist, men ikke minst, vil registeret hente inn opplysninger om den symptomlindrende oppfølgingen i siste levetid. Her vil Kommunalt pasient- og brukerregister og Reseptregisteret være viktige datakilder.

\section{Én kreftmelding}

Registerets arbeidsgruppe, med onkolog Hanne Hamre som leder, har bestått av fire medlemmer fra Norsk Gastrointestinal Cancer Gruppes faggruppe for kreftsykdom i lever, pankreas, galleblære og gallegang (NGICG-HPB), der Kristoffer Lassen er leder, en representant fra Norsk register for gastrokirurgi (NoRGast) og tre av Kreftregisterets medarbeidere.

Arbeidsgruppen har lagt stor vekt på at arbeidet med registrering for den enkelte lege og avdeling skal være redusert til et absolutt minimum. Det er lagt mye arbeid i en intuitiv og kortfattet kreftmelding. Pankreaskreftpasientene har ofte et oppsplittet forløp, der vurdering av tumors resektabilitet gjøres på universitetssykehus, mens utredning, kjemoterapi og øvrige prosedyrer foregår på lokalsykehuset.

Det er kun én kreftmelding som skal opprettes, nemlig ved utredningstidspunktet. Kreftmeldingen er lagt tett opp mot og utfyller det som allerede registreres i pakkeforløp (ㅁ). Øvrige opplysninger vil bli hentet fra Norsk pasientregister (ICD-koder og prosedyrekoder), NoRGast (risikoprofil, operasjonstype og komplikasjoner ved kirurgi), medikamentelle registre (Reseptregisteret, Chemotherapy Management System (CMS)), Dødsårsaksregisteret og andre registre med høy dekningsgrad. For at kvalitetsregisteret skal fungere etter hensikten, vil høy responsrate og komplett innmelding være den viktigste suksessfaktoren.

«For at kvalitetsregisteret skal fungere etter hensikten, vil høy

responsrate og komplett innmelding vare den viktigste suksessfaktoren»

På ett punkt skiller kreftmeldingen til kvalitetsregisteret for pankreaskreft seg fra andre kreftmeldinger. Tradisjonelt settes diagnosetidspunkt for kreftsykdom til dato for biopsi. Men ved pankreaskreft er det en høy andel som aldri biopseres, blant annet fordi biopsi/cytologi av pankreas fordrer kompetanse i form av endoskopisk ultralyd, noe mange utredende sykehus ikke har. Derfor ble det besluttet at diagnosetidspunkt skal legges til samme dato som sykdommen blir avdekket ved radiologisk undersøkelse.

\section{Nøkkelen til suksess}

Hvis dette registeret skal lykkes, vil det kreve noen minutters lojal deltagelse og ansvarlighet hver gang en pasient diagnostiseres med pankreaskreft! Oppgaven kan der og da tilfalle en kirurg, en onkolog eller en indremedisiner, men det er i disse minuttene 
registerets suksess avgjøres. Registerets fagledelse og Kreftregisterets analytikere skal ta ansvaret for at dette sammenstilles med data fra andre kilder og blir til robust informasjon som kommer pasientene og fagmiljøet til nytte.

\section{LITTERATUR}

1. Kreftregisteret. Cancer in Norway 2018. https://www.kreftregisteret.no/Generelt/Rapporter/Cancerin-Norway/cancer-in-norway-2018/ Lest 30.11.2020.

2. Rahib L, Smith BD, Aizenberg R et al. Projecting cancer incidence and deaths to 2030: the unexpected burden of thyroid, liver, and pancreas cancers in the United States. Cancer Res 2014; 74: 2913-21. [PubMed][CrossRef]

3. Huang L, Jansen L, Balavarca Y et al. Resection of pancreatic cancer in Europe and USA: an international large-scale study highlighting large variations. Gut 2019; 68: 130-9. [PubMed][CrossRef]

4. Conroy T, Desseigne F, Ychou M et al. FOLFIRINOX versus gemcitabine for metastatic pancreatic cancer. N Engl J Med 2011; 364: 1817-25. [PubMed][CrossRef]

5. Latenstein AEJ, van der Geest LGM, Bonsing BA et al. Nationwide trends in incidence, treatment and survival of pancreatic ductal adenocarcinoma. Eur J Cancer 2020; 125: 83-93. [PubMed] [CrossRef]

6. Helsedirektoratet. Bukspyttkjertelkreft.

https://www.helsedirektoratet.no/pakkeforlop/bukspyttkjertelkreft Lest 1.11.2020.

Publisert: 6. januar 2021. Tidsskr Nor Legeforen. DOI: 10.4045/tidsskr.20.0869

Mottatt 29.10.2020, første revisjon innsendt 20.11.2020, godkjent 30.11.2020.

(C) Tidsskrift for Den norske legeforening 2023. Lastet ned fra tidsskriftet.no 26. april 2023. 